\title{
Synthesis of $6 \alpha, 7 \beta$-Dihydroxyvouacapan-17 $\beta$-oic Acid Derivatives. Part IV: Mannich Base Derivatives and its Activities on the Electrically Stimulated Guinea-pig Ileum Preparation
}

\author{
Valdenir J. Belinelo ${ }^{a, b}$, Genuína T. Reis ${ }^{c}$, Guglielmo M. Stefani ${ }^{a}$, Dalton L. Ferreira-Alves ${ }^{d}$ \\ and Dorila Piló-Veloso ${ }^{*}$,
}

${ }^{a}$ Departamento de Química, ICEx, Universidade Federal de Minas Gerais, Av. Antônio Carlos, 6627, 31270-901 Belo Horizonte - MG, Brazil

${ }^{b}$ Centro de Ciências da Saúde, Universidade Severino Sombra, 27700-000 Vassouras - RJ, Brazil

${ }^{c}$ Departamento de Química, Universidade de Itaúna, 35680-033 Itaúna - MG, Brazil

${ }^{d}$ Departamento de Farmacologia, ICB, Universidade Federal de Minas Gerais, 31270-901 Belo Horizonte - MG, Brazil

\begin{abstract}
O ácido $6 \alpha, 7 \beta$-di-hidroxivouacapan-17 $\beta$-óico (ADV, 1), furanoditerpeno isolado dos frutos de Pterodon polygalaeflorus Benth, apresenta atividade analgésica em modelos laboratoriais utilizando roedores. Visando reunir dados para estudar a ação biológica de vouacapanóides, foram obtidas seis novas amidas derivadas (4-9), contendo grupos alquilaminas no anel furânico, preparadas pela reação de Mannich com sais de imínios pré-formados. Esses derivados tiveram suas estruturas determinadas pela análise de dados espectroscópicos no IV, RMN de ${ }^{1} \mathrm{He}$ de ${ }^{13} \mathrm{C}$ e foram submetidos a triagem farmacológica in vitro, destinada a detectar substâncias com ação depressora sobre células neuronais.
\end{abstract}

The furanditerpene $6 \alpha, 7 \beta$-dihydroxyvouacapan-17 $\beta$-oic acid (ADV, 1), isolated from Pterodon polygalaeflorus Benth fruits, presents analgesic activity in current rodent experimental models. With the aim to gather data for biological studies it were obtained six new amide derivatives substituted in the furan ring with alkylamine groups, prepared by the Mannich reaction with preformed iminium salts. These derivatives were evaluated in a preliminary in vitro pharmacological test. Structures were determined by spectroscopic data of IR, ${ }^{1} \mathrm{H}$ and ${ }^{13} \mathrm{C}$ NMR.

Keywords: furanditerpenes, vouacapanoids, Pterodon polygalaeflorus, analgesics, Mannich bases

\section{Introduction}

The genus Pterodon (Leguminosae) comprises five species widely distributed over central Brazil, among which Pterodon polygalaeflorus Benth, popularly known as "Sucupira-branca" and "Faveiro". ${ }^{2}$ In Brazilian folk medicine, the alcoholic extracts made from seeds of this vegetal are used as anti-rheumatic, antiinflammatory (sore throat) and analgesic preparations. ${ }^{3-8}$

From the hexanic extract of the P. polygalaeflorus Benth fruits linear diterpenes and furanditerpenes were isolated and identified. ${ }^{9-13}$ The most ubiquitous furanditerpene was $6 \alpha, 7 \beta$-di-hydroxyvouacapan-17 $\beta$-oic

*e-mail:dorila@dedalus.lcc.ufmg.br acid $\mathbf{1}$ (ADV). This compound presented analgesic activity in current rodent experimental models. ${ }^{9-11}$ Therefore, aiming to obtain information on chemical structure and biological activity relationships and to search for more potent compounds, several derivatives of ADV have been synthesized. ${ }^{6,712-17}$ The ADV presents groups that may be both donor and acceptor of hydrogen bonds. For comparison studies here we report both the synthesis and identification of six new amide derivatives (4-9) presenting only acceptor of hydrogen bonds and the results of in vitro biological screening test. These compounds have furan ring substituted with amino groups at carbon-16, obtained by Mannich reaction with preformed iminium salts. The structures were determined on the basis of IR, NMR in one and two-dimensional spectroscopic techniques, including COSY, HMQC, and HMBC. 


\section{Experimental}

All reactions were followed by analytical thin-layer chromatography (TLC, Merck Silica gel 60G, 2:3 ethyl ether:dichloromethane). Melting points were measured on a Mettler FP 82 HT and were not corrected. Elemental analysis were obtained on a Perkin Elmer 2400 apparatus. Infrared (IR) were recorded using nujol or $\mathrm{KBr}$ disks on a Mattson Instruments FTIR 3000. ${ }^{1} \mathrm{H}$ and ${ }^{13} \mathrm{C}$ NMR spectra were recorded on Bruker DPX 200 AVANCE $\left({ }^{1} \mathrm{H}\right.$ : $200 \mathrm{MHz}$; $\left.{ }^{13} \mathrm{C}: 50 \mathrm{MHz}\right)$ and DRX 400 AVANCE $\left({ }^{1} \mathrm{H}: 400 \mathrm{MHz} ;{ }^{13} \mathrm{C}\right.$ : $100 \mathrm{MHz}$ ) spectrometers, in $\mathrm{CDCl}_{3}$ taking TMS as internal standard $(\delta=0)$. ADV Mannich bases derivatives were prepared as indicate in Scheme 1, according to the methods described below. ${ }^{1}$ Compound 2 were obtained as reported before: rdt. 95\%; mp 219.6-221.5 (lit. ${ }^{12} 219.8-221.3$ ).

Preparation of $N$-Ethyl-N-methyl-6 $\alpha, 7 \beta$-dimethoxyvouacapan-17 $\beta$-amide (3)

To a stirred solution of $500 \mathrm{mg}(1.34 \mathrm{mmol})$ of amide 2 in $25.0 \mathrm{~mL}$ of THF is added $500 \mathrm{mg}(20.8 \mathrm{mmol})$ of sodium hydride. After $20 \mathrm{~min}$ at room temperature, $0.8 \mathrm{~mL}(12.8$ $\mathrm{mmol}$ ) of methyl iodide is added. The reaction is monitored by TLC, and after $42 \mathrm{~h}$ is poured over crushed ice. The mixture is filtered, the solid is washed with water, and recrystallized from 1:1 ethanol:water. A white powder is obtained with $93 \%$ yield; mp $190-191{ }^{\circ} \mathrm{C}$; IR (nujol) $v_{\max } / \mathrm{cm}^{-1}: 2980,2920,2840,1643,1509,1299,1227$, 1135, 1095, 1050, 1017, 960, 940, 931, 722; ${ }^{1} \mathrm{H}$ NMR $\left(\mathrm{CDCl}_{3}, 400 \mathrm{MHz}\right) \delta 0.96\left(\mathrm{dt}, 1 \mathrm{H}, J_{\text {lax,leq }}=J_{\text {lax, }, 2 \mathrm{ax}} 13.5 \mathrm{~Hz}\right.$, $\left.J_{\text {lax, 2eq }} 3.6 \mathrm{~Hz}, \mathrm{H}-1 \mathrm{ax}\right), 0.99$ (s, 3H, H-20), 1.03 (s, 3H, H-19), 1.09 (d, $\left.1 \mathrm{H}, J_{5,6} 11.2 \mathrm{~Hz}, \mathrm{H}-5\right), 1.12$ (s, 3H, H-18), 1.20 (t, $\left.3 \mathrm{H}, J_{2,1}, 7.1 \mathrm{~Hz}, \mathrm{H}-2^{\prime}\right), 1.20$ (dt, $1 \mathrm{H}, J_{3 \text { ax, } 3 \mathrm{eq}}=J_{\text {3ax, } 2 \mathrm{ax}} 13.5 \mathrm{~Hz}$, $\left.J_{3 \mathrm{ax}, 2 \mathrm{eq}} 3.6 \mathrm{~Hz}, \mathrm{H}-3 \mathrm{ax}\right), 1.37$ (td, $1 \mathrm{H}, J_{3 \text { eq, }, 3 \mathrm{x}} 13.5 \mathrm{~Hz}, J_{3 \mathrm{eq}, 2 \mathrm{eq}}=$ $\left.J_{3 \text { eq,2ax }} 3.6 \mathrm{~Hz}, \mathrm{H}-3 \mathrm{eq}\right), 1.40-1.48$ (m, 2H, H-9 and H-2eq), 1.55 (tq, $1 \mathrm{H}, J_{2 \mathrm{ax}, 2 \mathrm{eq}}=J_{\text {2ax, 1ax }}=J_{\text {2ax }, 3 \mathrm{ax}} 13.5 \mathrm{~Hz}, J_{\text {2ax, leq }}=J_{\text {2ax }, \text { eq }}$ $3.6 \mathrm{~Hz}, \mathrm{H}-2 \mathrm{ax}$ ), 1.66 (ddt, $1 \mathrm{H}, J_{\text {leq, lax }} 13.5 \mathrm{~Hz}, J_{\text {leq,2ax }}=J_{\text {leq,2eq }}$ $\left.3.6 \mathrm{~Hz}, J_{\text {leq, }, \text { eq }} 1.8 \mathrm{~Hz}, \mathrm{H}-1 \mathrm{eq}\right), 2.40$ (ddd, $1 \mathrm{H}, J_{11 \text { ax, }, 1 \text { leq }} 16.2$ $\left.\mathrm{Hz}, J_{11 \mathrm{ax} .9} 11.0 \mathrm{~Hz}, J_{11 \mathrm{ax}, 14} 2.4 \mathrm{~Hz}, \mathrm{H}-11 \mathrm{ax}\right), 2.62(\mathrm{dd}, 1 \mathrm{H}$, $\left.J_{11 \text { eq, } 1 \text { lax }} 16.2 \mathrm{~Hz}, J_{11 \text { eq, } 9} 5.2 \mathrm{~Hz}, \mathrm{H}-11 \mathrm{eq}\right), 2.66-2.75(\mathrm{~m}, 1 \mathrm{H}$, $\mathrm{H}-8), 2.96$ (dd, $\left.1 \mathrm{H}, J_{7,8} 10.1 \mathrm{~Hz}, J_{7,6} 9.6 \mathrm{~Hz}, \mathrm{H}-7\right), 2.99-3.12$ (m, 1H, H-14), 3.27 (s, 3H, H-1"), 3.45-3.55 (m, 2H, H-1'),
3.54 (s, 3H, $\mathrm{CH}_{3} \mathrm{O}-7$ ), 3.56 (s, 3H, $\left.\mathrm{CH}_{3} \mathrm{O}-6\right), 3.55-3.75$ (m, $1 \mathrm{H}, \mathrm{H}-6), 6.03$ (d, 1H, $\left.J_{15,16} 1.4 \mathrm{~Hz}, \mathrm{H}-15\right), 7.20$ (d, 1H, $J_{16,15}$ $1.4 \mathrm{~Hz}, \mathrm{H}-16$ ); ${ }^{13} \mathrm{C}$ NMR (see Table 3); Anal. Calcd. for $\mathrm{C}_{25} \mathrm{H}_{39} \mathrm{NO}_{4}$ : C, 71.94\%; H, 9.35\%; N, 3.36\%; Found: C, $71.86 \% ; \mathrm{H}, 9.43 \%$; N $3.41 \%$.

General experimental procedure for the preparation of Mannich bases

The compounds 4-9 were obtained by Mannich reaction of $\mathrm{N}$-ethyl-N-methyl- $6 \alpha, 7 \beta$-dimethoxyvouacapan-17 $\beta$-amide (3) with preformed N,Ndialkylmethyleniminium chloride salts (Table 1 and Scheme 1), in $81-98 \%$ yields. ${ }^{18}$ To a stirred solution of $0.20 \mathrm{mmol}$ of the respective preformed iminium salts in 10 $\mathrm{mL}$ of THF at room temperature under nitrogen is added $0.20 \mathrm{mmol}$ of amide $3 \mathrm{in} 10 \mathrm{~mL}$ of THF. Then, the reaction mixture is stirred under reflux for X hours (see Table 1) and temperatures and allowed to cool to room temperature, and monitored by TLC. The mixture is poured into $25 \mathrm{~mL}$ of water, and $\mathrm{NH}_{4} \mathrm{OH}$ is added until $\mathrm{pH} 8$, to precipitate the product. After filtration, the precipitate is applied to a column of silic gel (0.063-0.200 mm, Merck). Elution with 3:2 ethyl ether:dichloromethane affords white solides in Y\% yields (see Table 1).

$N$-Ethyl-N-methyl-16-(N,N-dimethylaminomethyl)$6 \alpha, 7 \beta$-dimethoxyvouacapan-17 $\beta$-amide (4): white powder, mp 146-148 ${ }^{\circ} \mathrm{C}$; IR (KBr) $v_{\max } / \mathrm{cm}^{-1}: 2920,2870,1650$, 1450, 1420, 1380, 1320, 1270, 1230, 1200, 1140, 1100, 1030, 980, 950, 850, 800, 745, 700; ${ }^{1} \mathrm{H}$ NMR (see Table 2); ${ }^{13} \mathrm{C}$ NMR (see Table 3); Anal. Calcd. for $\mathrm{C}_{28} \mathrm{H}_{46} \mathrm{~N}_{2} \mathrm{O}_{4}$ : C, $70.85 \%$; H, 9.77\%; N, 5.90\%; Found: C, 70.53\%; H, 9.74\%; N, $5.93 \%$.

$N$-Ethyl-N-methyl-16-( $N, N$-diethylaminomethyl)$6 \alpha, 7 \beta$-dimethoxyvouacapan-17 $\beta$-amide (5): white powder, $\mathrm{mp} 119-121^{\circ} \mathrm{C}$; IR (KBr) $v_{\max } / \mathrm{cm}^{-1}: 2960,2920,2850,1660$, 1560, 1470, 1410, 1380, 1340, 1300, 1280, 1240, 1200, $1150,1135,1100,1030,980,950,850,830,800,770$, 750, 740, 700; ${ }^{1} \mathrm{H}$ NMR (see Table 2); ${ }^{13} \mathrm{C}$ NMR (see Table 3); Anal. Calcd. for $\mathrm{C}_{30} \mathrm{H}_{50} \mathrm{~N}_{2} \mathrm{O}_{4}$ : C, 71.67\%; $\mathrm{H}, 10.02 \%$; , 5.57\%; Found: C, $72.00 \%$; H, $10.08 \%$; N, 5.65\%.

Table 1. Summary of the data for the preparation of the Mannich bases

\begin{tabular}{|c|c|c|c|c|c|}
\hline Compound & $\begin{array}{c}\text { time/temperature } \\
\mathrm{X}\end{array}$ & $\begin{array}{c}\text { Yield (\%) } \\
\text { Y }\end{array}$ & Compound & $\begin{array}{c}\text { time/temperature } \\
\mathbf{X}\end{array}$ & $\begin{array}{l}\text { Yield }(\%) \\
\mathbf{Y}\end{array}$ \\
\hline 4 & $1.5 \mathrm{~h} / 70^{\circ} \mathrm{C}$ & 81.4 & 7 & $1.0 \mathrm{~h} / 70^{\circ} \mathrm{C}$ & 93.1 \\
\hline 5 & $1.5 \mathrm{~h} / 70^{\circ} \mathrm{C}$ & 98.2 & 8 & $1.0 \mathrm{~h} / 70^{\circ} \mathrm{C}$ & 83.0 \\
\hline 6 & $2.0 \mathrm{~h} / 70^{\circ} \mathrm{C}$ & 96.3 & 9 & $1.0 \mathrm{~h} / 70^{\circ} \mathrm{C}$ & 92.6 \\
\hline
\end{tabular}




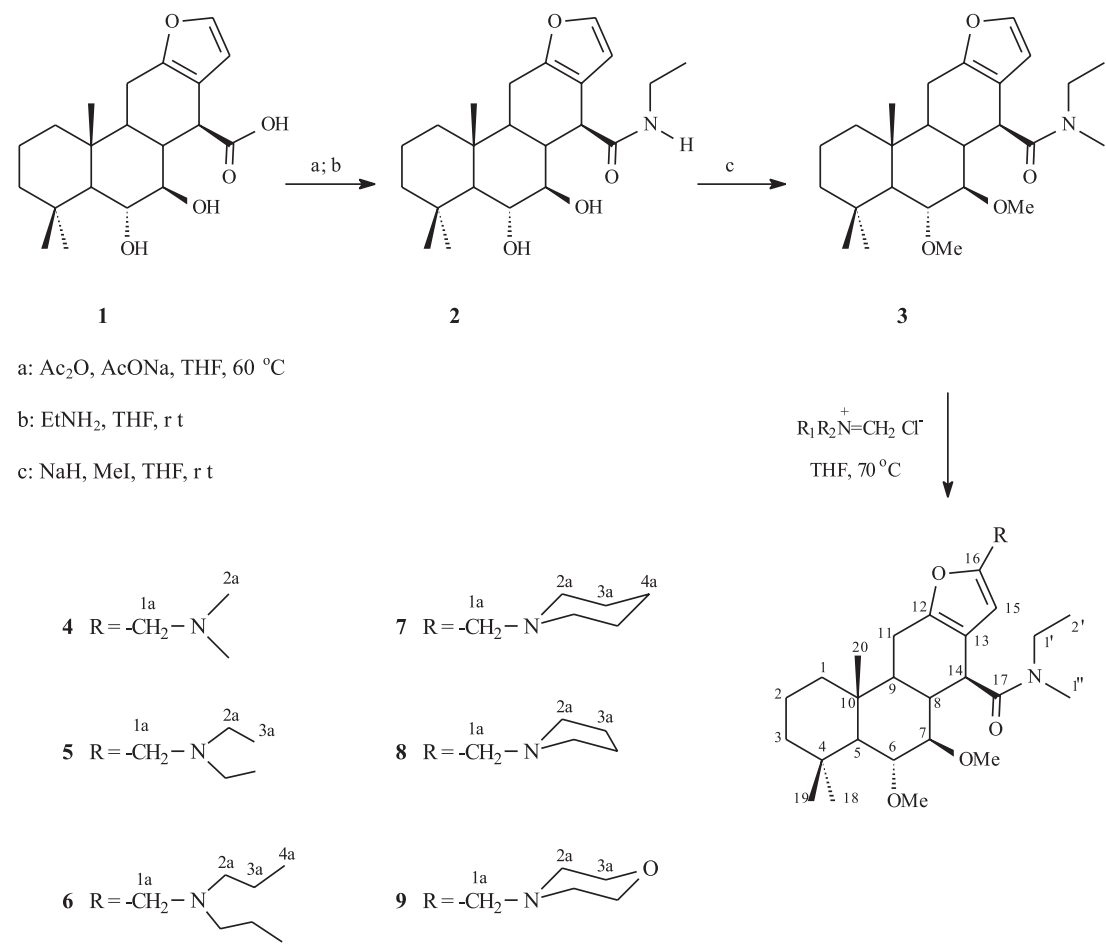

Scheme 1.

$N$-Ethyl- $N$-methyl-16-( $N, N$-dipropylaminomethyl)$6 \alpha, 7 \beta$-dimethoxyvouacapan-17 $\beta$-amide $(\mathbf{6})$ : white powder, mp 128-132 ${ }^{\circ} \mathrm{C}$; IR (KBr) $v_{\max } / \mathrm{cm}^{-1}: 2920,2870,1650$, 1570, 1460, 1400, 1380, 1340, 1300, 1270, 1250, 1230, $1200,1190,1140,1100,1070,1030,980,950,830,800$, 745, 700; ${ }^{1} \mathrm{H}$ NMR see Table 2 ); ${ }^{13} \mathrm{C}$ NMR (see Table 3); Anal. calcd. for $\mathrm{C}_{32} \mathrm{H}_{54} \mathrm{~N}_{2} \mathrm{O}_{4}: \mathrm{C}, 72.41 \% ; \mathrm{H}, 10.25 \%$; N, 5.28\%; Found: C, $72.05 \%$; H, $10.29 \%$; N, $5.31 \%$.

$N$-Ethyl-N-methyl-16-(1-piperidylmethyl)-6 $\alpha, 7 \beta$ dimethoxyvouacapan-17 $\beta$-amide (7): white powder, mp $138-139{ }^{\circ} \mathrm{C}$; IR (KBr) $v_{\max } / \mathrm{cm}^{-1}: 2960,2920,2850,1640$, $1575,1550,1450,1420,1380,1350,1320,1300,1270$, 1220, 1190, 1150, 1135, 1100, 1075, 1050, 1030, 1025, $1000,970,950,940,920,870,850,830,745,700 ;{ }^{1} \mathrm{H}$ NMR (see Table 2); ${ }^{13} \mathrm{C}$ NMR (see Table 3); Anal. Calcd. for $\mathrm{C}_{31} \mathrm{H}_{50} \mathrm{~N}_{2} \mathrm{O}_{4}$ : C, $72.33 \% ; \mathrm{H}, 9.79 \%$; N, 5.44\%. Found: C, $72.71 \% ; \mathrm{H}, 9.70 \% ; \mathrm{N}, 5.50 \%$.

$N$-Ethyl-N-methyl-16-(1-pyrrolidinylmethyl)-6 $\alpha, 7 \beta$ dimethoxyvouacapan-17 $\beta$-amide (8): white powder, mp $156-160{ }^{\circ} \mathrm{C}$; IR (KBr) $v_{\max } / \mathrm{cm}^{-1}: 2930,2880,1650,1580$, 1460, 1440, 1400, 1380, 1350, 1320, 1300, 1280, 1240, $1200,1150,1100,1030,990,940,880,830,740,700 ;{ }^{1} \mathrm{H}$ NMR (see Table 2); ${ }^{13} \mathrm{C}$ NMR (see Table 3); Anal. Calcd. for $\mathrm{C}_{30} \mathrm{H}_{48} \mathrm{~N}_{2} \mathrm{O}_{4}: \mathrm{C}, 71.96 \% ; \mathrm{H}, 9.66 \%$; N, 5.59\%; Found: $\mathrm{C}, 72.29 \% ; \mathrm{H}, 9.70 \% ; \mathrm{N}, 5.62 \%$.
$N$-Ethyl-N-methyl-16-(4-morpholinylmethyl)-6 $\alpha, 7 \beta-$ dimethoxyvouacapan-17 $\beta$-amide (9): white powder, $\mathrm{mp}$ $181-184{ }^{\circ} \mathrm{C}$; IR (KBr) $v_{\max } / \mathrm{cm}^{-1}: 2920,2870,1650,1460$, $1420,1385,1360,1320,1230,1200,1150,1120,1080$, 1010, 990, 940, 920, 880, 800, 740, 700; ${ }^{1} \mathrm{H}$ NMR (see Table 2); ${ }^{13} \mathrm{C}$ NMR (see Table 3); Anal. Calcd. for $\mathrm{C}_{30} \mathrm{H}_{48} \mathrm{~N}_{2} \mathrm{O}_{5}: \mathrm{C}, 69.73 \%$; H, 9.36\%; N, 5.42\%; Found: C, $68.40 \%$; H, $9.41 \%$; N. $5,47 \%$.

\section{Biological assay}

In vivo tests for analgesia in rat or mice usually requires gram amounts of derivatives. Thus, it was selected one in vitro screening test that could be predictive for a pharmacological action upon neuronal cells. The guineapig ileum electrically stimulated is able to detect actions on smooth-muscle cells (post-synaptic effects) and actions on neuronal cells (pre-synaptic effects). ${ }^{19}$ Previous analysis showed that in the dose range below $10^{-4} \mathrm{~mol} \mathrm{~L}^{-1}$, the action of ADV derivatives is inhibitory and mainly pre-synaptic in this biological preparation. The data hence obtained correlated reasonably with the analgesic activity measured in mice (writhing assay). ${ }^{11}$ In performing the test, the derivatives (3-9) were firstly dissolved in DMSO (2.50x $10^{-2} \mathrm{~mol} \mathrm{~L}^{-1}$ ) and then added to the biological preparation suspended in aqueous nutritional media for a final concentration of $2.50 \times 10^{-5} \mathrm{~mol} \mathrm{~L}^{-1}$. The guinea-pig ileum 
was prepared according to the technique of Paton and $\mathrm{Zar}^{19}$ with some modifications: A) animals, male and female white guinea-pigs weighting about $600.00 \mathrm{~g}$, obtained from the bioterium of Ezequiel Dias Foundation (MG-BH) were sacrificed by neck dislocation, the abdomen opened and a piece of about fifty $\mathrm{cm}$ long of the terminal ileum excised and washed internally with Krebs solution until all intestinal contents were eliminated; B) a piece of about fifteen $\mathrm{cm}$ was then cut and turned inside-out around a plastic rod, the mucosal layer being removed by gentle abrasion with surgical cotton soaked with Krebs solution and turned again to the pristine anatomical configuration; C) pieces of two $\mathrm{cm}$ long were them tied, the bottom to a rodlike plastic support to be placed inside the organ bath cuvette and the top extremity to an electronic force transducer by means of a thin polyester string, without closing the intestinal lumen; D) modified Krebs solution was composed of $\mathrm{Na}^{+}\left(1.38 \times 10^{-5} \mathrm{~mol} \mathrm{~L}^{-1}\right) ; \mathrm{Cl}^{-}\left(1.38 \times 10^{-5}\right.$ mol L-1); $\mathrm{K}^{+}\left(6.00 \times 10^{-3} \mathrm{~mol} \mathrm{~L}^{-1}\right) ; \mathrm{Ca}^{++}\left(2.50 \times 10^{-3} \mathrm{~mol} \mathrm{~L}^{-1}\right)$; $\mathrm{Mg}^{++}\left(1.20 \times 10^{-3} \mathrm{~mol} \mathrm{~L}^{-1}\right)$; Tris (hidroxymethyl)aminomethane $\left(6.25 \times 10^{-3} \mathrm{~mol} \mathrm{~L}^{-1}\right) ; \mathrm{HCO}_{3}^{-}\left(1.25 \times 10^{-4} \mathrm{~mol} \mathrm{~L}^{-1}\right)$; Dextrose $\left(1.11 \times 10^{-4} \mathrm{~mol} \mathrm{~L}^{-1}\right)$ and choline $\left(0.01 \times 10^{-3} \mathrm{~mol} \mathrm{~L}^{-1}\right)$ maintained thermostatically at $37^{\circ} \mathrm{C}$ and aerated by atmospheric air; E) electric stimulation was performed through two platinum electrodes placed $4.5 \mathrm{~cm}$ apart each other inside the cuvette with square direct current pulses $(10 \mathrm{v} / \mathrm{cm}, 0.05 \mathrm{~Hz}, 1 \mathrm{~ms}$ duration) generated by a physiological stimulator; F) recording was made using chart potentiometric recorders after proper calibration of transducer $(\mathrm{cm} / \mathrm{g})$. Each cycle of measurement of activity was composed of a control period of five minutes of registration of normal $(100 \%)$ contracture responses to electric stimulation followed by exposition to the test drug for ten minutes. After that the nutritional media was changed repeatedly until full recover of control level contractures was attained. The assays were always made comparative to $\mathrm{ADV}$ at the same concentration. The results were expressed as the increase in the percentage inhibition of contractures caused by the derivative in relation to that caused by ADV after ten minutes of addition of the drug. To evaluate the post-synaptic effects, i.e. inhibition of contractility of intestinal smooth muscle cells in itself, a maximal dose of acetylcholine was added to the cuvette over the test drug at the moment of maximum inhibition after the electric stimulation had been turned off. The response thus obtained was then compared with control responses to added acetylcholine in equal dose.

\section{Results and Discussion}

With the aim to producing ADV derivatives without hydrogen bond donors, the amide $\mathbf{2}$ was obtained as previously reported ${ }^{12}$ and then reacted with excess of sodium hydride to produce N-ethyl-N-methyl- $6 \alpha, 7 \beta$ dimethoxyvouacapan-17 $\beta$-amide (amide 3, Scheme 1). This is a new compound whose structure was determined by comparison with compound $\mathbf{2}$, by means of both IR and NMR spectra analysis. No bands due to $\mathrm{OH}$ stretching were observed in the IR spectrum of compound $\mathbf{3}$ and its ${ }^{1} \mathrm{H}$ and ${ }^{13} \mathrm{C}$ NMR characteristic signals were observed respectively at $\delta_{\mathrm{H}}: 3.27\left(\mathrm{H}-1\right.$ "), $3.54\left(\mathrm{CH}_{3} \mathrm{O}-7\right)$, and $3.56\left(\mathrm{CH}_{3} \mathrm{O}-6\right)$; and at $\delta_{\mathrm{C}}: 42.9(\mathrm{C}-1$ ") $), 59.5\left(\mathrm{CH}_{3} \mathrm{O}-7\right)$ and $60.4\left(\mathrm{CH}_{3} \mathrm{O}-6\right)$. These signals were assigned with the help of HMQC and HMBC techniques.

The methodology in Scheme 1 for the preparation of the Mannich bases ADV derivatives 4-9 employs preformed $\mathrm{N}, \mathrm{N}$-dialkylmethyleniminium chloride salts previously prepared as described in the literature. ${ }^{18}$ The good yields obtained for all derivatives (81-98\%, Table 1) suggest the reaction non dependence of the alkylamino substituent structure. This was the most efficient synthetic route for this preparation since tentative to utilize the classical Mannich reaction ${ }^{20,21}$ did not result in good yields.

Comparisons between amide 3 structure and those of compounds 4-9 by ${ }^{1} \mathrm{H}$ NMR spectra analysis of the signals in the region of aromatic hydrogen resonance were very efficient to verify the success of the Mannich reaction. For the kind of furanditerpene studied, only the furan ring hydrogen signals are observed in that spectral region. Therefore, the disappearance of the signal that in amide 3 spectrum is observed for $\mathrm{H}-16$ at $\delta 7.20(\mathrm{~d}, J 1.4 \mathrm{~Hz})$, in the form of a doublet because of the coupling with the H-15 $\left(\delta_{\mathrm{H}} 6.03, J 1.4 \mathrm{~Hz}\right)$, may be used to confirm the planned Mannich base structures. In all the compounds 4 to $9{ }^{1} \mathrm{H}$ NMR spectra it was observed only a single signal between $\delta_{\mathrm{H}} 5.86$ and 5.80 at the aromatic region, assigned to the respective $\mathrm{H}-15$.

The region of aliphatic hydrogen resonances of the ${ }^{1} \mathrm{H}$ NMR spectra registered for ADV derivatives was complex in some, showing superposition of signals, but well resolved in others. The interpretation was facilitated with the help of 2D COSY, HMQC, and HMBC techniques.

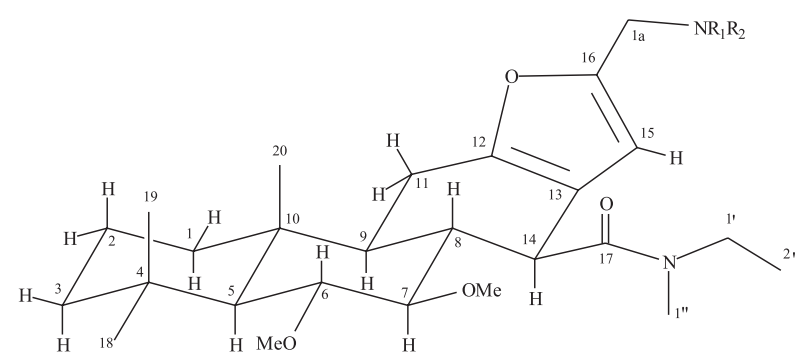

For compounds 4-9, the ${ }^{1} \mathrm{H}$ NMR signals of all similar 
Table 2. ${ }^{1} \mathrm{H}$ NMR spectral data of the ADV derivatives 4 to $9\left(\mathrm{CDCl}_{3}, 400 \mathrm{MHz}\right)$

\begin{tabular}{|c|c|c|c|c|c|c|}
\hline Atom & $\stackrel{4}{\delta(\mathrm{m}) ; \mathrm{J} / \mathrm{Hz}}$ & $\stackrel{5}{\mathbf{5}} \delta(\mathrm{m}) ; \mathrm{J} / \mathrm{Hz}$ & $\delta(\mathrm{m}) ; \mathrm{J} / \mathrm{Hz}$ & $\begin{array}{c}7 \\
\delta(\mathrm{m}) ; \mathrm{J} / \mathrm{Hz}\end{array}$ & $\begin{array}{c}\mathbf{8} \\
\delta(\mathrm{m}) ; \mathrm{J} / \mathrm{Hz}\end{array}$ & $\delta \stackrel{9}{9}$ \\
\hline H-1 ax & $\begin{array}{l}0.94(\mathrm{td}) \\
13.0 ; 3.6\end{array}$ & $\begin{array}{l}0.98(\mathrm{td}) \\
13.6 ; 3.2\end{array}$ & $\begin{array}{l}0.95(\mathrm{td}) \\
13.0 ; 3.4\end{array}$ & $0.89-1.03(\mathrm{~m})$ & $\begin{array}{l}0.94(\mathrm{td}) \\
13.0, \quad 3.6\end{array}$ & $\begin{array}{l}0.94(\mathrm{td}) \\
13.2,3.6\end{array}$ \\
\hline $\mathrm{H}-1 \mathrm{eq}$ & $\begin{array}{c}1.65 \text { (brd); } \\
13.0\end{array}$ & $\begin{array}{c}1.65 \text { (brd); } \\
13.6\end{array}$ & $\begin{array}{c}1.66(\mathrm{brd}) ; \\
13.0\end{array}$ & $1.65-1.70(\mathrm{~m})$ & $\begin{array}{l}1.65(\mathrm{dt}) \\
13.0,3.6\end{array}$ & $\begin{array}{l}1.64(\mathrm{dt}) \\
13.2,3.6\end{array}$ \\
\hline H-2ax & $\begin{array}{l}1.55(\mathrm{qt}) \\
13.0,3.6\end{array}$ & $\begin{array}{l}1.55(\mathrm{qt}) \\
13.6,3.2\end{array}$ & $1.48-1.62(\mathrm{~m})$ & $1.51-1.55(\mathrm{~m})$ & $\begin{array}{l}1.55(\mathrm{qt}) \\
13.0, \quad 3.6\end{array}$ & $\begin{array}{l}1.55(\mathrm{qt}) \\
13.2, \quad 3.6\end{array}$ \\
\hline $\mathrm{H}-2 \mathrm{eq}$ & $1.40-1.46(\mathrm{~m})$ & $1.30-1.48(\mathrm{~m})$ & $1.30-1.48(\mathrm{~m})$ & $1.36-1.47(\mathrm{~m})$ & $1.35-1.49(\mathrm{~m})$ & $1.40-1.46(\mathrm{~m})$ \\
\hline H-3ax & $\begin{array}{l}1.19(\mathrm{td}) \\
13.0,3.6\end{array}$ & $\begin{array}{l}1.23(\mathrm{td}) \\
13.6,3.2\end{array}$ & $1.20-1.28(\mathrm{~m})$ & $\begin{array}{l}1.19(\mathrm{td}) \\
13.2,4.0\end{array}$ & $\begin{array}{l}1.22(\mathrm{td}) \\
13.0,3.6\end{array}$ & $\begin{array}{l}1.19(\mathrm{td}) \\
13.2,3.6\end{array}$ \\
\hline $\mathrm{H}-3 \mathrm{eq}$ & $1.30-1.43(\mathrm{~m})$ & $1.30-1.48(\mathrm{~m})$ & $1.30-1.48(\mathrm{~m})$ & $1.24-1.36(\mathrm{~m})$ & $1.35-1.49(\mathrm{~m})$ & $1.30-1.43(\mathrm{~m})$ \\
\hline $\mathrm{H}-5$ & $\begin{array}{l}1.08(\mathrm{~d}) \\
11.2\end{array}$ & $\begin{array}{c}1.08(\mathrm{~d}) \\
10.4\end{array}$ & $\begin{array}{c}1.08(\mathrm{~d}) \\
11.1\end{array}$ & $\begin{array}{c}1.08(\mathrm{~d}) \\
11.1\end{array}$ & $\begin{array}{c}1.08(\mathrm{~d}) \\
11.1\end{array}$ & $\begin{array}{c}1.08(\mathrm{~d}) \\
11.1\end{array}$ \\
\hline H-6 & $3.42-3.62(\mathrm{~m})$ & $3.42-3.61(\mathrm{~m})$ & $3.43-3.65(\mathrm{~m})$ & $3.44-3.55(\mathrm{~m})$ & $3.42-3.61(\mathrm{~m})$ & $3.43-3.59(\mathrm{~m})$ \\
\hline $\mathrm{H}-7$ & $\begin{array}{c}2.97(\mathrm{dd}) \\
9.7,9.5\end{array}$ & $\begin{array}{c}2.96(\mathrm{dd}) \\
10.1,9.2\end{array}$ & $\begin{array}{l}2.96(\mathrm{dd}) \\
10.5,8.6\end{array}$ & $\begin{array}{c}2.96(\mathrm{dd}) \\
9.7,9.1\end{array}$ & $\begin{array}{c}2.96(\mathrm{dd}) \\
9.6, \quad 9.5\end{array}$ & $\begin{array}{c}2.96(\mathrm{dd}) \\
9.8, \quad 9.2\end{array}$ \\
\hline $\mathrm{H}-8$ & $2.61-2.72(\mathrm{~m})$ & $2.63-2.74(\mathrm{~m})$ & $2.65-2.73(\mathrm{~m})$ & $2.61-2.72(\mathrm{~m})$ & $2.50-2.75(\mathrm{~m})$ & $2.55-2.73(\mathrm{~m})$ \\
\hline $\mathrm{H}-9$ & $1.30-1.43(\mathrm{~m})$ & $1.30-1.48(\mathrm{~m})$ & $1.30-1.48(\mathrm{~m})$ & $1.36-1.47(\mathrm{~m})$ & $1.35-1.49(\mathrm{~m})$ & $1.30-1.43(\mathrm{~m})$ \\
\hline H-11ax & $\begin{array}{c}2.37(\mathrm{ddd}) \\
16.0,11.4,2,6\end{array}$ & $\begin{array}{c}2.36(\mathrm{ddd}) \\
16.1,11.1,2.3\end{array}$ & $2.30-2.45(\mathrm{~m})$ & $2.30-2.48(\mathrm{~m})$ & $2.33-2.46(\mathrm{~m})$ & $\begin{array}{c}2.37(\mathrm{ddd}) \\
16.2,11.2,2.4\end{array}$ \\
\hline $\mathrm{H}-11 \mathrm{eq}$ & $\begin{array}{l}2.61(\mathrm{dd}) \\
16.0,5.2\end{array}$ & $\begin{array}{l}2.61(\mathrm{dd}) \\
16.1,5.2\end{array}$ & $\begin{array}{c}2.60(\mathrm{dd}) \\
16.2,5.7\end{array}$ & $\begin{array}{l}2.61(\mathrm{dd}) \\
16.1,5.2\end{array}$ & $2.50-2.75(\mathrm{~m})$ & $2.55-2.73(\mathrm{~m})$ \\
\hline $\mathrm{H}-14$ & $2.99-3.13(\mathrm{~m})$ & $2.99-3.10(\mathrm{~m})$ & $2.99-3.10(\mathrm{~m})$ & $2.99-3.13(\mathrm{~m})$ & $2.99-3.10(\mathrm{~m})$ & $2.99-3.10(\mathrm{~m})$ \\
\hline H- 15 & $5.84(\mathrm{~s})$ & $5.82(\mathrm{~s})$ & $5.80(\mathrm{~s})$ & $5.85(\mathrm{~s})$ & $5.85(\mathrm{~s})$ & $5.86(\mathrm{~s})$ \\
\hline $\mathrm{CH}_{3}-18$ & $1.11(\mathrm{~s})$ & $1.11(\mathrm{~s})$ & $1.11(\mathrm{~s})$ & $1.11(\mathrm{~s})$ & $1.11(\mathrm{~s})$ & $1.11(\mathrm{~s})$ \\
\hline $\mathrm{CH}_{3}^{3}-19$ & $1.02(\mathrm{~s})$ & $1.02(\mathrm{~s})$ & $1.02(\mathrm{~s})$ & $1.02(\mathrm{~s})$ & $1.02(\mathrm{~s})$ & $1.02(\mathrm{~s})$ \\
\hline $\mathrm{CH}_{3}^{3}-20$ & $0.97(\mathrm{~s})$ & $0.97(\mathrm{~s})$ & $0.98(\mathrm{~s})$ & $0.97(\mathrm{~s})$ & $0.97(\mathrm{~s})$ & $0.97(\mathrm{~s})$ \\
\hline $\mathrm{CH}_{2}^{3}-1$ & $3.42-3.62(\mathrm{~m})$ & $3.42-3.61(\mathrm{~m})$ & $3.43-3.65(\mathrm{~m})$ & $3.44-3.55(\mathrm{~m})$ & $3.42-3.61(\mathrm{~m})$ & $3.43-3.59(\mathrm{~m})$ \\
\hline $\mathrm{CH}_{3}^{2}-2$ & $\begin{array}{c}1.18(\mathrm{t}) \\
7.2\end{array}$ & $\begin{array}{c}1.18(\mathrm{t}) \\
7.3\end{array}$ & $\begin{array}{c}1.16(\mathrm{t}) \\
7.0\end{array}$ & $\begin{array}{c}1.18(\mathrm{t}) \\
7.2\end{array}$ & $\begin{array}{c}1.18(\mathrm{t}) \\
7.2\end{array}$ & $\begin{array}{c}1.18(\mathrm{t}) \\
7.1\end{array}$ \\
\hline $\mathrm{CH}_{3}-1$, & $3.26(\mathrm{~s})$ & $3.27(\mathrm{~s})$ & $3.27(\mathrm{~s})$ & $3.26(\mathrm{~s})$ & $3.26(\mathrm{~s})$ & $3.27(\mathrm{~s})$ \\
\hline $\mathrm{CH}_{3} \mathrm{O}-7$ & $3.53(\mathrm{~s})$ & $3.53(\mathrm{~s})$ & $3.53(\mathrm{~s})$ & $3.53(\mathrm{~s})$ & $3.53(\mathrm{~s})$ & $3.53(\mathrm{~s})$ \\
\hline $\mathrm{CH}_{3}^{3} \mathrm{O}-6$ & $3.60(\mathrm{~s})$ & $3.56(\mathrm{~s})$ & $3.56(\mathrm{~s})$ & $3.56(\mathrm{~s})$ & $3.56(\mathrm{~s})$ & $3.56(\mathrm{~s})$ \\
\hline $\mathrm{CH}_{2}-1 \mathrm{a}$ & $\begin{array}{l}3.31 \text { (d); } 13.9 \\
3.38 \text { (d); } 13.9\end{array}$ & $3.42-3.61(\mathrm{~m})$ & $3.43-3.65(\mathrm{~m})$ & 3.40 (brs) & $3.42-3.61(\mathrm{~m})$ & 3.41 (brs) \\
\hline $\mathrm{H}-2 \mathrm{a}$ & $2.24(\mathrm{~s})$ & $2.52(q) ; 7.1$ & $2.30-2.45(\mathrm{~m})$ & $2.30-2.48(\mathrm{~m})$ & $2.50-2.75(\mathrm{~m})$ & 2.45 (brs) \\
\hline $\mathrm{H}-3 \mathrm{a}$ & $2.24(\mathrm{~s})$ & $\begin{array}{c}1.05(\mathrm{t}) \\
7.1\end{array}$ & $\begin{array}{c}1.48(\operatorname{sex}) \\
7.4\end{array}$ & $\begin{array}{c}1.60(\mathrm{qn}) \\
5.7\end{array}$ & $1.72-1.85(\mathrm{~m})$ & $\begin{array}{c}3.72(\mathrm{t}) \\
4.6\end{array}$ \\
\hline $\mathrm{H}-4 \mathrm{a}$ & - & - & $\begin{array}{c}0.86(\mathrm{t}) \\
7.4\end{array}$ & $1.36-1.47(\mathrm{~m})$ & - & - \\
\hline
\end{tabular}

m: multiplicity (in parentheses).

methyl groups presented the same or very near chemical shifts. Hence, they were observed as singlets at $\delta_{\mathrm{H}}$ 0.97 - 0.98 range $(\mathrm{H}-20), 1.02(\mathrm{H}-19), 1.11(\mathrm{H}-18), 3.26$ or 3.27 ( $\mathrm{H}-1 "), 3.53\left(\mathrm{CH}_{3} \mathrm{O}-7\right)$, and $3.56\left(\mathrm{CH}_{3} \mathrm{O}-6\right)$.

In the spectra of compounds $\mathbf{4 , 5}$ and $\mathbf{9}$ it was assigned to the respective hydrogen 11 ax a very well resolved double double doublet at $\delta_{\mathrm{H}} 2.36$ or 2.37 , with ${ }^{2} J_{\text {gem }}$ $16.0-16.2 \mathrm{~Hz},{ }^{3} J_{11 \text { ax }, 9} 11.1-11.4 \mathrm{~Hz}(\Delta J 0.3 \mathrm{~Hz})$ and ${ }^{5} J_{11 \text { ax }, 14}$ $2.3-2.6 \mathrm{~Hz}(\Delta J 0.3 \mathrm{~Hz})$. The difference in the $J$ value is not significant. The long range ${ }^{5} \mathrm{~J}$ between $\mathrm{H}-11 \mathrm{ax}$ and $\mathrm{H}-$ 14 is due to homoallylic coupling. For the other compounds, the respective signals of $\mathrm{H}-11 \mathrm{ax}$ are superposed to the ones of $\mathrm{H}-2 \mathrm{a}\left(\delta_{\mathrm{H}} 2.30-2.48\right)$.

From these data it could be inferred that all ADV derivatives 4-9 present similar furanditerpene skeletal conformations. However, in their ${ }^{1} \mathrm{H}$ NMR spectra it was also verified that the respective hydrogen $\mathrm{H}-7$ resonances showed a double doublet at $\delta_{\mathrm{H}} 2.96$ or 2.97 with ${ }^{3} J_{7,6}$ $8.6-9.5 \mathrm{~Hz}(\Delta J 0.9 \mathrm{~Hz})$ and ${ }^{3} J_{7,8} 9.6-10.5 \mathrm{~Hz}(\Delta J 0.9 \mathrm{~Hz})$. In these cases, the $J$ value variation for different compounds is greater than the related above for $\mathrm{H}-11 \mathrm{ax}$. This means that the dihedral angles between $\mathrm{H}-7 / \mathrm{H}-6$ and $\mathrm{H}-7 / \mathrm{H}-8$ differ from one compound to the other. These differences may be due to the aminomethylene groups because all the other substituents of the furanditerpene framework are identical in this kind of compounds.

The ${ }^{1} \mathrm{H}$ NMR signal of hydrogen $\mathrm{H}-3 \mathrm{a}$ of the cyclic aminomethylene groups substituents (Scheme 1) at C-16 
appeared as a quintet at $\delta_{\mathrm{H}} 1.60\left({ }^{3} \mathrm{~J}_{3 \mathrm{a}, 2 \mathrm{a}}={ }^{3} J_{3 \mathrm{a}, 4 \mathrm{a}} 5.7 \mathrm{~Hz}\right)$ for compound 7, as multiplet between $\delta_{\mathrm{H}} 1.72-1.85$ for compound $\mathbf{8}$, and as a triplet at $\delta_{\mathrm{H}} 3.72$ for compound $\mathbf{9}$. This indicates the greater flexibility of the six ring amines (7 and 9) when compared to the five ring amine (8).

Table 3 shows the ${ }^{13} \mathrm{C}$ NMR spectra data for compounds 3 to 9 . The assignments were done by comparing 1D routine ${ }^{13} \mathrm{C}$ NMR and DEPT 135 techniques in combination with both 2D HMQC and HMBC techniques.

From this table it may be seen a great similarity of the behavior of these compounds as detected by the ${ }^{13} \mathrm{C}$ NMR. Nevertheless, some observed small differences may be explored. The signals between $\delta_{\mathrm{C}} 151.0$ (compound 4) and 149.8 (compound 9) for all the compounds were assigned to the respective $\mathrm{C}-16$. The $\mathrm{C}-16$ more shielded is the one of compound $\mathbf{9}$, presenting the smaller $\Delta \delta 0.8$ as calculated from compound $6\left(\delta_{\mathrm{C}}\right.$ 150.6). By other way, being non hydrogenated, all these carbons are more deshielded by comparison with the $\mathrm{C}-16$ of compound $\mathbf{3}\left(\delta_{\mathrm{C}} 141.2\right)$. These observations could also be used as a diagnostic to confirm the substitution in the furan ring of $\mathbf{3}$ by Mannich reaction. However, by means of its HMBC correlation with both $\mathrm{H}$ 9 and $\mathrm{H}-14$, the respective signals of $\mathrm{C}-12$ for all these compounds were assigned between $\delta_{\mathrm{C}} 151.5$ and 150.7, and, in some cases, their values were superposed with that of C-16 (compounds 4 and 7). Because of these identical or approximate ${ }^{13} \mathrm{C}$ NMR chemical shift values observed between $\mathrm{C}-12$ and $\mathrm{C}-16$ of this series of compounds, the ${ }^{1} \mathrm{H}$ NMR provides the more precise information to confirm that reaction success.

The ${ }^{13} \mathrm{C}$ NMR signals of the aminomethylene groups C-1a and C-2a of compounds $\mathbf{6}$ and $\mathbf{8}$ present some peculiar differences when compared with the corresponding signals of compounds 5, 7, and $\mathbf{9}$. For these, the $\delta_{\mathrm{C}}$ (respectively 49.3, 55.8, and 55.6) of the $\mathrm{C}-1 \mathrm{a}$ are more deshielded than those of C-2a ( $\delta_{\mathrm{C}}$ respectively $46.6,54.2$, and 53.4). The inverse is observed for the similar carbon resonances of compounds $\mathbf{6}$ and $\mathbf{8}$ that show: C-1a respectively at $\delta_{\mathrm{C}}$ 50.4 and 52.2 while C-2a are respectively at $\delta_{\mathrm{C}} 55.7$ and 53.8 .

\section{Biological assays}

The prostaglandins produced by neighboring cells or by the nerve itself induces a situation of pain hipersensitivity referred in the specialized literature as

Table 3. ${ }^{13} \mathrm{C}$ NMR chemical shifts $(d)$ of the ADV derivatives 3 to $9\left(\mathrm{CDCl}_{3}\right)^{\text {a }}$

\begin{tabular}{|c|c|c|c|c|c|c|c|}
\hline Atom & 3 & 4 & 5 & 6 & 7 & 8 & 9 \\
\hline C-1 & 39.7 & 39.8 & 39.6 & 39.7 & 39.6 & 39.6 & 39.8 \\
\hline C-2 & 18.4 & 18.5 & 18.4 & 18.5 & 18.4 & 18.4 & 18.5 \\
\hline C-3 & 44.1 & 44.2 & 44.1 & 42.9 & 44.0 & 44.0 & 44.2 \\
\hline C-4 & 33.4 & 33.6 & 33.4 & 33.5 & 33.4 & 33.4 & 33.6 \\
\hline C-5 & 57.0 & 57.1 & 57.0 & 57.0 & 57.0 & 56.9 & 57.1 \\
\hline C-6 & 84.5 & 84.6 & 84.6 & 84.6 & 86.1 & 84.5 & 84.5 \\
\hline C-7 & 93.9 & 93.9 & 93.9 & 94.1 & 93.9 & 93.9 & 93.9 \\
\hline C-8 & 40.4 & 40.5 & 40.3 & 40.3 & 40.3 & 40.3 & 40.4 \\
\hline C-9 & 48.4 & 48.6 & 48.3 & 48.4 & 48.3 & 48.3 & 48.5 \\
\hline C-10 & 38.3 & 38.4 & 38.3 & 38.2 & 38.3 & 38.7 & 38.4 \\
\hline C-11 & 22.0 & 22.1 & 22.1 & 22.1 & 22.0 & 22.0 & 22.2 \\
\hline C-12 & 151.3 & 151.0 & 151.1 & 151.5 & 150.7 & 151.3 & 151.4 \\
\hline C-13 & 113.9 & 114.6 & 114.2 & 114.3 & 114.2 & 114.3 & 114.7 \\
\hline C-14 & 32.9 & 32.9 & 32.9 & 32.9 & 32.9 & 32.8 & 32.9 \\
\hline C- -15 & 107.8 & 106.8 & 106.6 & 107.0 & 106.9 & 106.1 & 107.5 \\
\hline C-16 & 141.2 & 151.0 & 150.7 & 150.6 & 150.7 & 150.7 & 149.8 \\
\hline C- 17 & 173.4 & 173.5 & 173.4 & 173.5 & 173.5 & 173.4 & 173.4 \\
\hline C-18 & 36.3 & 36.4 & 36.3 & 36.4 & 36.3 & 36.3 & 36.3 \\
\hline C-19 & 22.9 & 23.0 & 22.9 & 23.0 & 22.9 & 22.9 & 23.0 \\
\hline C- 20 & 15.4 & 15.5 & 15.4 & 15.4 & 15.3 & 15.3 & 15.5 \\
\hline $\mathrm{C}-1{ }^{\prime}$ & 42.9 & 43.0 & 42.9 & 44.1 & 42.8 & 42.8 & 43.0 \\
\hline C-2' & 12.2 & 12.2 & 12.2 & 12.2 & 12.2 & 12.2 & 12.2 \\
\hline C-1" & 35.2 & 35.3 & 35.2 & 35.3 & 35.2 & 35.2 & 35.3 \\
\hline $\mathrm{CH}_{3} \mathrm{O}(\mathrm{C}-6)$ & 59.5 & 59.5 & 59.5 & 59.5 & 59.5 & 59.4 & 59.5 \\
\hline $\mathrm{CH}_{3}^{3} \mathrm{O}(\mathrm{C}-7)$ & 60.4 & 60.3 & 60.5 & 60.6 & 60.5 & 60.4 & 60.2 \\
\hline $\mathrm{C}-1 \mathrm{a}$ & - & 56.1 & 49.3 & 50.4 & 55.8 & 52.2 & 55.6 \\
\hline $\mathrm{C}-2 \mathrm{a}$ & - & 45.0 & 46.6 & 55.7 & 54.2 & 53.8 & 53.4 \\
\hline$C-3 a$ & - & 45.0 & 11.6 & 20.0 & 25.7 & 23.4 & 66.8 \\
\hline$C-4 a$ & - & - & - & 11.9 & 24.1 & - & - \\
\hline
\end{tabular}

a - 4 and 9 at $100 \mathrm{MHz} ; \mathbf{5 - 8}$ at $50 \mathrm{MHz}$. 
"inflammatory hyperalgesia". Thus, the inhibitors of ciclooxygenases of araquidonic acid are analgesics because they prevent prostaglandins production. ${ }^{22}$ Morphine and related opioides are pharmacological agents whose analgesic actions result exclusively from a range of cellular actions upon neurons that causes a increase of threshold for cell excitation and inhibition of synaptic transmission in pain transmission pathways. The actions of opioides on neuronal cells of the myenteric plexus, that are responsible for the decrease of intestinal movements, are mediated by the same receptors and same cellular mechanisms that operate in analgesia. ${ }^{23}$ The electrically stimulated guineapig ileum is the classical biological preparation for the assay of opioides, due to its sensitivity $\left(10^{-9} \mathrm{~mol} \mathrm{~L}^{-1}\right)$ and specificity, being instrumental for the discovery of endogenous opioides. ${ }^{24}$ Another pharmacological class of analgesic compounds is now in development, the alpha2adrenergic receptor agonists. ${ }^{25}$ These compounds can also be detected and assayed in the electrically stimulated guinea-pig ileum where they cause inhibition of acetylcholine liberation in parasympathetic nerve endings and hence diminution of the electrically induced contractures. ${ }^{26}$ The furanditerpenes related to ADV cause inhibition of the guinea-pig ileum induced contractions by a mechanism still not cleared but not related to the opioide and alpha 2 adrenergic receptors. The fact that this effect correlates with the analgesia obtained in mice (in vivo test) is an empirical finding ${ }^{27}$ that enables its use just for screening.

Table 4 shows the inhibition of the guinea-pig stimulated contractions, induced by a fixed concentration (2.5 $\times 10^{-5}$ mol.L $\left.\mathrm{L}^{-1}\right)$ of the ADV derivatives 3-9, expressed as increase in the percentage inhibition above that caused by ADV itself. The antiinflammatory non-steroidal analgesics are not detected by this kind of assay.

Table 4. Percentage increase of the inhibition above that caused by $\operatorname{ADV}\left(2.5 \times 10^{-5} \mathrm{~mol} \mathrm{~L}^{-1}\right)$ of the electrically stimulated guinea-pig ileum contractions for the ADV derivatives 3-9

\begin{tabular}{cccc}
\hline Compound & Inhibition (\%) & Compound & Inhibition (\%) \\
\hline $\mathbf{3}$ & 8.2 & $\mathbf{7}$ & 12.8 \\
$\mathbf{4}$ & 10.0 & $\mathbf{8}$ & 13.0 \\
$\mathbf{5}$ & 11.0 & $\mathbf{9}$ & 30.8 \\
$\mathbf{6}$ & 12.0 & - & - \\
\hline
\end{tabular}

The opioides and alpha-2 adrenergic agonists are very active but not included in Table 4 as standards due to the difference in mechanism of action. All seven ADV derivatives showed enhancement of the ability to inhibit the electrically stimulated guinea-pig ileum contractions.
The increase in the $\mathrm{N}$-alkyl substituent carbon chain (compounds 4-8) caused almost no modification of activity. The compound 9 was significantly the more active. The explanation for that could reside in the fact that in this kind of biological assay, the tissue is suspended in a nutritional aqueous media in which compound 9 was completely soluble at the test concentration while all others formed fine suspensions. A through pharmacological study in vivo implies a high expenditure of the test compounds which is hardly feasible or actually unnecessary for all members of an homologous chemical series. The objective of performing an in vitro previous screening test, besides the fact that no one in vitro assay could exactly predict analgesic activity, is to provide evidence for the choice of the most promising compounds. Thus compound 9 and one the most active $\mathrm{N}$-alkyl substituted derivatives $\mathbf{4}$ to $\mathbf{8}$, must be submitted to in vivo pharmacological studies.

\section{Acknowledgments}

The authors thank the Fundação de Amparo à Pesquisa de Minas Gerais (FAPEMIG) for financial support. Professor D. Piló-Veloso received research fellowship (Conselho Nacional de Desenvolvimento Científico e Tecnológico) and V. J. Belinelo received graduate scholarship (CNPq).

\section{References}

1. This work is part of Belinelo, V. J.; Ph. D. Thesis, Universidade Federal de Minas Gerais, Belo Horizonte, Brazil, 2002.

2. Correa, M.P.; Dicionário de Plantas Úteis do Brasil e das Plantas Exóticas Cultivadas, MA-IBDF, Imprensa Nacional: Rio de Janeiro, 1978, p. 153.

3. Mors, W. B.; Santos-Filho, M. F.; Monteiro, H. J.; Gilbert, B.; Science 1967, 157, 950.

4. Mahajan, J. R.; Monteiro, M. B.; J. Chem. Soc., Perkin Trans. 1 1973, 520.

5. Fascio, M.; Mors, W. B.; Gilbert, B.; Mahajan, J. R.; Monteiro, M. B.; Santos-Filho, M. F.; Vichnewski, W.; Phytochemistry 1976, 15, 201.

6. Rubinger, M. M. M.; Piló-Veloso, D.; Stefani, G. M.; J. Braz. Chem. Soc. 1991, 2, 124.

7. Maltha, C. R. A.; Stefani, G. M.; Piló-Veloso, D.; J. Braz. Chem. Soc. 1995, 6, 357.

8. Nunan, E. A.; Carvalho, M. G.; Piló-Veloso, D.; TurchettiMaia, R. M. M.; Ferreira-Alves, D. L.; Braz. J. Med. Biol. Res. 1982, 15, 450 .

9. Demuner, A. J.; Barbosa, L. C. A.; Piló-Veloso, D.; FerreiraAlves, D. L.; Howarth, O. W.; J. Nat. Prod. 1996, 59, 770.

10. Duarte, I. D. G.; Ferreira-Alves, D. L.; Nakamura-Craig, M.; Life Sciences 1992, 50, 891. 
11. Duarte, I. D. G.; Ferreira-Alves, D. L.; Piló-Veloso, D.; Nakamura-Craig, M.; J. Ethnopharmacol. 1996, 55, 13.

12. Maltha, C. R. A.; Stefani, G. M.; Piló-Veloso, D.; FerreiraAlves, D. L.; J. Braz. Chem. Soc. 1997, 8, 203.

13. Abrahão-Junior, O.; Gambardella, M. T. P.; Ruggiero, S. G.; Sacramento, T. M.; Stefani, G. M.; Piló-Veloso, D.; Acta Cryst. 1997, C53, 1508.

14. Demuner, A. J.; Barbosa, L. C. A.; Piló-Veloso, D.; Howarth, O. W.; Aust. J. Chem. 1998, 51, 61.

15. Branco, M. C.; Gambardella, M. T. P.; Ruggiero, S. G.; Maltha, C. R. A.; Stefani, G. M.; Piló-Veloso, D.; Acta Cryst. 1999, C55, 1297.

16. Belinelo, V. J.; Piló-Veloso, D.; Borges, E. L.; Ferreira-Alves, D. L.; Reis, G. T.; Eclet. Quim. 2001, 26, 25.

17. Teixeira, A. L.; Belinelo, V. J.; Piló-Veloso, D.; Borges, E. L.; Ferreira-Alves, D. L.; Reis, G. T.; Rev. Bras. Plant. Med. 2001, 38,37 .

18. Heaney, H.; Papageorgiou, G.; Wilkins, R. F.; Tetrahedron Lett. 1988, 29, 2377.
19. Paton, W. D. M.; Zar, A.; J. Physiol. Lond. 1968, 194, 13.

20. Tramontini, M.; Synthesis 1973, 703.

21. Arend, M.; Westeermann, B.; Risch, N.; Angew. Chem. Int. Ed. 1998, 37, 1044.

22. Vane, J. R.; Nature New Biology 1971, 231, 232.

23. Reisine, T.; Pasternak, G. In Goodman \& Gilman's The Pharmacological Basis of Therapeutics, $9^{\text {th }}$ ed.; Hardman J. G. and Limbird L. E., eds.; Mc Graw-Hill: New York, USA, 1995.

24. Hughes, J. W.; Smith, T.; Kosterlitz, H.; Fothergill, L.; Morgan, B.; Morris, H.; Nature 1975, 255, 577.

25. Boyd, R. E.; Current Top. Med. Chem. 2001, 1, 193.

26. Wikberg, J.; Acta Physiol. Scand. 1978, 103, 225.

27. Ferreira-Alves, D. L.; unpublished data.

Received: June 7, 2002

Published on the web: November 8, 2002 